\title{
Molecular characterization and mRNA expression of ribosomal protein L8 in Rana nigromaculata during development and under exposure to hormones
}

\author{
Qinqin $\mathrm{Lou}^{1,2}$, Shan $\mathrm{Cao}^{1,2}$, Wei Xu ${ }^{1,2}$, Yinfeng Zhang ${ }^{1}$, Zhanfen Qin ${ }^{1, *}$, Wuji Wei ${ }^{2}$
}

1. State Key Laboratory of Environmental Chemistry and Ecotoxicology, Research Center for Eco-environmental Sciences, Chinese Academy of Sciences, Beijing 100085, China. E-mail: louqinqindy@163.com

2. College of Environment, Nanjing University of Technology, Nanjing 210009, China

\section{A R T I C L I N F O}

Article history:

Received 15 November 2013

Revised 22 January 2014

Accepted 24 February 2014

Available online 26 September 2014

\section{Keywords:}

Ribosomal protein L8

Rana nigromaculata

Endocrine disrupting chemical

Quantitative RT-PCR

Reference gene

\begin{abstract}
A B S T R A C T
Like Xenopus laevis, some species of the Rana genus are also used to study endocrine disrupting chemicals (EDCs). Although ribosomal protein L8 (rpl8) is the most-used reference gene for analyzing gene expression by quantitative reverse transcription polymerase chain reaction in Rana, its suitability as the reference gene has never been validated in any species of the Rana genus. We characterized rpl8 cDNA in Rana nigromaculata, a promising native species in East Asia for assaying endocrine disrupting effects. We found that the rpl8 cDNA consisted of $919 \mathrm{bp}$ and encoded 257 amino acids, exhibiting high identities of amino acid sequence with known rpl8 in other Rana species. Then, we examined the stability of mRNA expression during development. Compared with elongation factor 1 alpha 1, another common housekeeping gene, neither stage-specific nor tissue-specific expression of the rpl8 gene was found in all tissues examined (brain, liver, intestine, tail, testis and ovary) during $R$. nigromaculata development. Finally, we investigated rpl8 expression under exposure to hormones. No change in rpl8 mRNA expression was found under exposure to thyroid hormone (T4) and estrogen (estradiol), whereas expression of the corresponding biomarker genes was induced. Our results show that rpl8 is an appropriate reference gene for analyzing gene expression by quantitative reverse transcription polymerase chain reaction for assaying EDCs using R. nigromaculata, and might also provide support for using rpl8 as a reference gene in other Rana species due to the high conservation of rpl8 among the Rana genus.

(c) 2014 The Research Center for Eco-Environmental Sciences, Chinese Academy of Sciences.
\end{abstract} Published by Elsevier B.V.

\section{Introduction}

Amphibians are an important class of experimental animals for biological and toxicological studies (Burggren and Warburton, 2007; Song et al., 2010). With the growing concern about endocrine disrupting chemicals (EDCs) in recent decades, in particular, amphibians are widely used to evaluate endocrine disrupting effects by environmental chemicals (Kloas and Lutz, 2006). Mostly, hey are used to evaluate reproductive endocrine disruption due to the high sensitivity of the reproductive system to sex hormones. Some EDCs have been demonstrated to induce the feminization of gonads and secondary sexual characteristics, transcription of estrogenic biomarkers, and sex hormone imbalance in amphibians (Hayes et al., 2006; Hogan et al., 2008; Qin et al., 2007). In addition, amphibians have become a unique biological model for studying thyroid-disrupting effects of EDCs because amphibian

\footnotetext{
* Corresponding author. E-mail: qinzhanfen@rcees.ac.cn (Zhanfen Qin).
} 
metamorphosis is controlled by thyroid hormone (TH) (Berg et al., 2009; Takase et al., 2007). Some endpoints have been well-developed in the amphibian model for studying thyroid disrupting effects, including the time to metamorphosis, limb growth, intestinal remodeling, TH level, and mRNA expression of TH-related genes (Fini et al., 2012; Heimeier and Shi, 2010).

In the literature, Xenopus laevis is the most-used model amphibian species for endocrine disruption research (Degitz et al., 2005; Hayes et al., 2006). In addition, some native amphibian species, especially some species of the Rana genus, such as Rana catesbeiana (Veldhoen et al., 2006), Rana pipiens (Croteau et al., 2009), Rana temporaria (Mortensen et al., 2006) and Rana rugosa (Oka et al., 2009), have also been used as experimental species for assaying the endocrine-disrupting effects of chemicals. Rana nigromaculata (also called as Pelophylax nigromaculatus) is a species of true frog distributed widely in East Asia. R. nigromaculata has been used by biological and toxicological researchers in East Asia due to some of its advantages as an experimental species such as a shorter generation time (one year) and larval period (6-7 weeks) and easier raising in laboratory with lower natural mortality rate (Li et al., 2009; Park et al., 2001; Yang et al., 2005). In particular, R. nigromaculata can be induced to breed by injecting luteinizing hormone releasing hormone and human chorionic gonadotropin accompanied by simulating rainfall in the laboratory. Moreover, our preliminary work has shown that R. nigromaculata is sensitive to estrogenic/ androgenic chemicals and thyroid-disrupting chemicals. Given its availability and these advantages, $R$. nigromaculata is suggested to be a promising native amphibian species in East Asia for evaluating reproductive endocrine disruption as well as thyroid-disrupting effects of chemicals.

As mentioned above, mRNA expression of some sex- and thyroid-related genes is one of the most-used endpoints for evaluating endocrine disrupting effects of EDCs in amphibians (Lehigh Shirey et al., 2006; Tan and Zoeller, 2007). Quantitative analysis of gene expression using quantitative reverse transcription polymerase chain reaction (qRT-PCR) typically requires the use of a constitutively expressed reference gene, which is adequately expressed in certain tissues with minimal variability in expression among samples under the experimental conditions used, as an internal control to normalize for differences in starting the cDNA template among samples (Arukwe, 2006; Huggett et al., 2005; Morse et al., 2005). Ribosomal protein L8 (rpl8) is a frequently used reference gene for normalizing gene expression in amphibians using qRT-PCR in previous studies (Gunderson et al., 2011; Hogan et al., 2007). However, nucleotide sequences of $r p l 8$ were characterized in only three species of the Rana genus, i.e., R. catesbeiana, Rana clamitans, and Rana sylvatica, in NCBI (www.ncbi.nlm.nih.gov). In particular, the suitability of rpl8 as a reference gene has never been validated in any species of the Rana genus. No information on the R. nigromaculata rpl8 gene is available in the literature, despite the fact that some researchers have used rpl8 as the reference gene in R. nigromaculata research (Zhang et al., 2013).

In this study, we aimed to characterize rpl8 cDNA and the stability of mRNA expression during development and under exposure to hormones, in order to validate rpl8 as an appropriate reference gene for qRT-PCR for assaying EDCs using R. nigromaculata and other species of the Rana genus. Also, we investigated the stability of mRNA expression of elongation factor 1 alpha 1 (ef1a1), another frequently used housekeeping gene in amphibian research, for comparison.

\section{Materials and methods}

\subsection{Animals and sampling}

Adult frogs (originally from Anhui Province) were raised in amphibious glass tanks with sand and dechlorinated water in our amphibian house and fed with Terzebrio molitor daily. Several pairs of adult frogs were induced to breed by injecting $15 \mu \mathrm{g}$ luteinizing hormone releasing hormone (Ningbo Second Hormone Factory, China) and human chorionic gonadotropin (Yantai North Pharmaceutical Co. Ltd., China; 300 IU for female, $200 \mathrm{IU}$ for male) dissolved in $0.6 \% \mathrm{NaCl}$, accompanied by simulating rainfall. Fertilized eggs were incubated in dechlorinated tap water and developed into stage 26 tadpoles (Gosner, 1960) on the 5th day postfertilization. The tadpoles were transferred into tadpole tanks with a water depth of $15 \mathrm{~cm}$ and fed with commercial diets (Totoro Supplies, Hong Kong, China) twice daily. The density of tadpoles in water was less than 1.5 tadpoles/L, and the water was changed twice per week. The tadpoles completed metamorphosis within 6-7 weeks postfertilization. The raising conditions for juvenile frogs were the same as those for adult frogs. In the amphibian house, fluorescent lighting provided a photoperiod of $12 \mathrm{hr}$ light:12 hr dark with a light intensity ranging from 600 to $1000 \mathrm{~lx}$ on the water surface. Water temperature was maintained at $(23 \pm 2)^{\circ} \mathrm{C}$.

To obtain the full length cDNA sequence of rpl8, we sampled the brain tissues from juvenile $R$. nigromaculata frogs (three months after metamorphosis) after anesthetizing with a $0.1 \%$ solution of 3-aminobenzoic acid ethyl ester (MS222, SigmaAldrich, Poole, UK). To compare the mRNA expression stability of rpl8 with ef1a1 during development, we sampled the tissues of brain, liver, intestine, tail, testis and ovary from the tadpoles at Gosner stages 26, 34, 39, 42 and 46 (Gosner, 1960) after anesthetization. The tissue samples were frozen immediately in liquid nitrogen, followed by storage at $-80^{\circ} \mathrm{C}$ until RNA extraction. All animal procedures were conducted according to Regulations for the Administration of Affairs Concerning Experimental Animals (State Science and Technology Commission of the People's Republic of China, 1988).

\subsection{Full length cDNA sequence of rpl8}

\subsubsection{RNA extraction and reverse transcription}

Total RNA was extracted from the brain tissues using TRIzol reagent (TIANGEN, Beijing, China). RNA concentration was measured with NanoDrop 2000 (Thermo Scientific, USA). RNA quality was verified by $A_{260 \mathrm{~nm}} / A_{280 \mathrm{~nm}}$ ratio in the range of 1.8-2.0 and by electrophoresis on ethidium bromide-stained $1.2 \%$ agarose gels. Then the RNA (1000 ng) was reverse transcribed into cDNA using a TIANScript RT Kit (TIANGEN, Beijing, China), following the manufacturer's instructions.

\subsubsection{RT-PCR and rapid amplification of CDNA ends}

The full-length cDNA sequence of rpl8 was generated by RT-PCR and rapid amplification of cDNA ends (RACE). The rpl8 CDNA fragments of $R$. nigromaculata were obtained by RT-PCR. Pairs of PCR primers of rpl8 were designed according to the known sequence of $R$. catesbeiana in the NCBI GenBank 
database (Table 1). To obtain the $3^{\prime}$ end and $5^{\prime}$ end sequences of rpl8, nested rapid amplification of cDNA ends PCR was performed using a GeneRacer Kit (Invitrogen, USA) according to the manufacturer's instructions. On the basis of the partial fragment sequences of rpl8, two pairs of gene specific primer (GSP) were designed for $3^{\prime}$-RACE and 5'-RACE (Table 1). The sequence of rpl8 was determined by Sanger sequencing (Invitrogen, Shanghai, China). Full-length cDNA of rpl8 was assembled by its internal core fragment, 5'-RACE fragment and $3^{\prime}$-RACE fragment.

\subsubsection{Sequence analysis}

The cDNA sequence and deduced amino acid sequence were analyzed using BLASTn and BLASTp, respectively. The open reading frame was found by ORF Finder in NCBI (www.ncbi. nlm.nih.gov). The sequence alignments were carried out using CLUSTAL X.

\section{3. mRNA expressions of rpl8 and ef1a1 during development}

Total RNA extraction and the first-strand cDNA synthesis were as described above. qRT-PCR was performed using a Real-time Polymerase Chain Reaction system (Mx3005P, Strategere, USA) and SYBR Green RealMasterMix (TIANGEN, Beijing, China). Specific primers for rpl8 and ef1a1 are shown in Table 1. The primers for ef1a1 were designed according to the known sequence of $X$. laevis (NM_001087442.1). The PCR conditions were as follows: $95^{\circ} \mathrm{C}$ for $2 \mathrm{~min}, 40$ cycles at $95^{\circ} \mathrm{C}$ for $20 \mathrm{sec}, 60^{\circ} \mathrm{C}$ for $30 \mathrm{sec}$, and $68^{\circ} \mathrm{C}$ for $30 \mathrm{sec}$.

\subsection{Exposure to $\mathrm{TH}$ and the response of rpl8, ef1a1 and $\mathrm{TH}$ receptors}

In amphibian research assaying thyroid-disrupting effects of chemicals, THs (T3 and T4) are often used as positive

Table 1 - Primers used for rapid amplification of cDNA ends (RACE) and quantitative RT-PCR (qRT-PCR).

\begin{tabular}{|c|c|c|}
\hline Primer & & Sequence \\
\hline \multicolumn{3}{|c|}{ Primers for partial fragment } \\
\hline rpl8-F & & 5'-TTCAGCGAGTTTACCAAGATCATCAC-3' \\
\hline rpl8-R & & 5'-TTAGACTTCCTGATCCTCAAAGACCTC-3' \\
\hline \multicolumn{3}{|c|}{ Primers for $3^{\prime}$-RACE PCR } \\
\hline 3'GSP1 & & 5'-CCAAGAAGGTCATCTCATC-3' \\
\hline 3'GSP2 & & 5'-CTCCAAGAAGGTCATCTCATC-3' \\
\hline \multicolumn{3}{|c|}{ Primers for 5'-RACE PCR } \\
\hline 5'GSP1 & & 5'-CAGATAGACGAGCTTTAGTTC-3' \\
\hline 5'GSP2 & & 5'-GAAGTTATCAGATAGACGAGCT-3' \\
\hline \multicolumn{3}{|r|}{ Primers for qRT-PCR } \\
\hline Gene & $\begin{array}{c}\text { PCR } \\
\text { efficiency }\end{array}$ & Sequence \\
\hline rpl8-F & $99.9 \%$ & 5'-GCTGTCGACTTCGCAGAAAGGCA-3' \\
\hline rpl8-R & & 5'-ACCTGTAAGGGTCACGGAAGGCA-3' \\
\hline efla1-F & $99.7 \%$ & 5'-CTTGCTATGCACCTGTGCTG-3' \\
\hline ef1a1-R & & 5'-CACATGGGCTTGCCAGGGAT-3' \\
\hline$E R \alpha-F$ & $108.0 \%$ & 5'-ACAAGAACCAGGGGCGTTG-3' \\
\hline$E R \alpha-R$ & & 5'-CATCATCCGGAAACGTGTAGC-3' \\
\hline TR $\beta$-F & $99.7 \%$ & 5'-GCTAGATGACTGTGCGTGGT-3' \\
\hline $\operatorname{TR} \beta-\mathrm{R}$ & & 5'-ACAGGAATAGCTTGGGTGAAGA-3' \\
\hline
\end{tabular}

reference chemicals, with mRNA expression of TH receptors (TRs, especially TR $\beta$ ) as molecular biomarkers (Fini et al., 2012; Hinther et al., 2011). To evaluate the stability of rpl8 and ef1a1 mRNA expression under exposure to thyroid-disrupting chemicals, we performed a 2-day experiment, in which $R$. nigromaculata tadpoles at stage 27 were exposed to a series of concentrations of T4 $(0.01,0.1,1,10,100,1000 \mathrm{nmol} / \mathrm{L})$ in tanks. T4 was dissolved in distilled water to prepare a stock solution concentration. Each tank contained $400 \mathrm{~mL}$ dechlorinated water and 6 tadpoles. The experimental water was completely replaced daily. The raising conditions for the tadpoles were as described above. At the end of the exposure, intestine tissues of the tadpoles were sampled and RNA in the intestine was extracted. qRT-PCR for rpl8 and ef1a1 were conducted as described above. The primers for TR $\beta$ of R. nigromaculata followed our previous study (GenBank accession number: KC139355), as shown in Table 1. The PCR conditions for TR $\beta$ were as follows: $95^{\circ} \mathrm{C}$ for $2 \mathrm{~min}$, followed by 40 cycles of $95^{\circ} \mathrm{C}$ for $20 \mathrm{sec}, 63^{\circ} \mathrm{C}$ for $30 \mathrm{sec}$ and $68^{\circ} \mathrm{C}$ for $30 \mathrm{sec}$.

\subsection{Exposure to estradiol and the response of rpl8, ef1a1 and estrogen receptor}

Because estrogen can induce mRNA expression of its receptor (estrogen receptor, ER) (Tata et al., 1993), ER expression is regarded as a molecular biomarker for estrogenic effects in amphibian research, with estradiol (E2) as a positive reference chemical (Kloas et al., 2009; Lutz et al., 2005). To examine the stability of rpl8 and ef1a1 mRNA expression under exposure to estrogenic chemicals, we conducted a 4-day E2-exposure experiment of $R$. nigromaculata tadpoles. The tadpoles at Gosner stage 42 were exposed to E2 (1, 10, $100 \mathrm{nmol} / \mathrm{L}$, DMSO as the solvent) for 4 days in glass tanks. Each tank contained $8 \mathrm{~L}$ dechlorinated water and 10 tadpoles. The experimental water was completely replaced daily. The raising conditions for the tadpoles were as described above. At the end of the exposure, the gonads of the tadpoles were sampled and fixed for sex identification by hematoxylin and eosin stain. The liver tissues of the tadpoles were sampled, and RNA was extracted following the methods mentioned above. The qRT-PCR for rpl8 and ef1a1 was conducted as described above. Specific primers for ER $\alpha$ were designed according to the sequence of Rana Rugosa (AB491673.1) and shown in Table 1. The PCR conditions for ER $\alpha$ were as follows: $95^{\circ} \mathrm{C}$ for $2 \mathrm{~min}$, followed by 40 cycles of $95^{\circ} \mathrm{C}$ for $20 \mathrm{sec}, 65^{\circ} \mathrm{C}$ for $30 \mathrm{sec}$ and $68^{\circ} \mathrm{C}$ for $30 \mathrm{sec}$.

\subsection{Statistical analysis}

Statistical analyses were performed using SPSS software version 16.0 (SPSS, USA). Experimental data were expressed as mean \pm SD. The expression of rpl8 during development was shown by the Ct (cycle threshold) value and analyzed by one-way analysis of variance. The fold changes of $E R \alpha$ and $\mathrm{TR} \beta$ expression were quantified by normalizing to rpl8 and determined by $2^{-\Delta \Delta C t}$. Statistical difference was assessed by one-way analysis of variance. Post-hoc comparison was made using Dunnett's test. Statistical significance was defined as $p \leq 0.05$. 


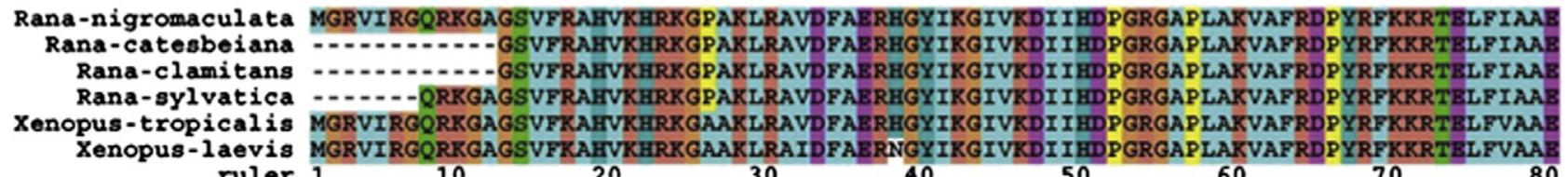

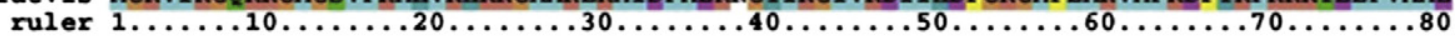
Rana-nigromaculata GIHTGQFVYCGKKAOLNI GNVLPVGTMP EGTIVCCVBEKPGDRGKLARASGNYATVISHNPETKKTRVKLPSGSKKVISS 160 Rana-catesbeiana GIHTGQFVYCGKKAQLNI GNVLPVGTMP EGTIVCCVBEKPGDRGKLARA SGNYATVI SHNP ETKKTRVKLPSGSKKVIS Rana-clamitans GIHTGQFVYCGKKA QLNI GNVLPVGTMP EGTIVCCVBEK PGDRGKLARA SGNYATVI SHNP ETKKTRVKLP SGSKKVIS Rama-aylvatica GI 作

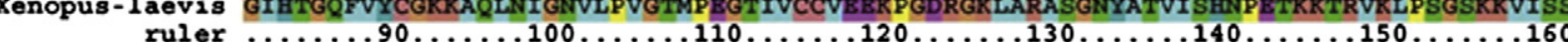
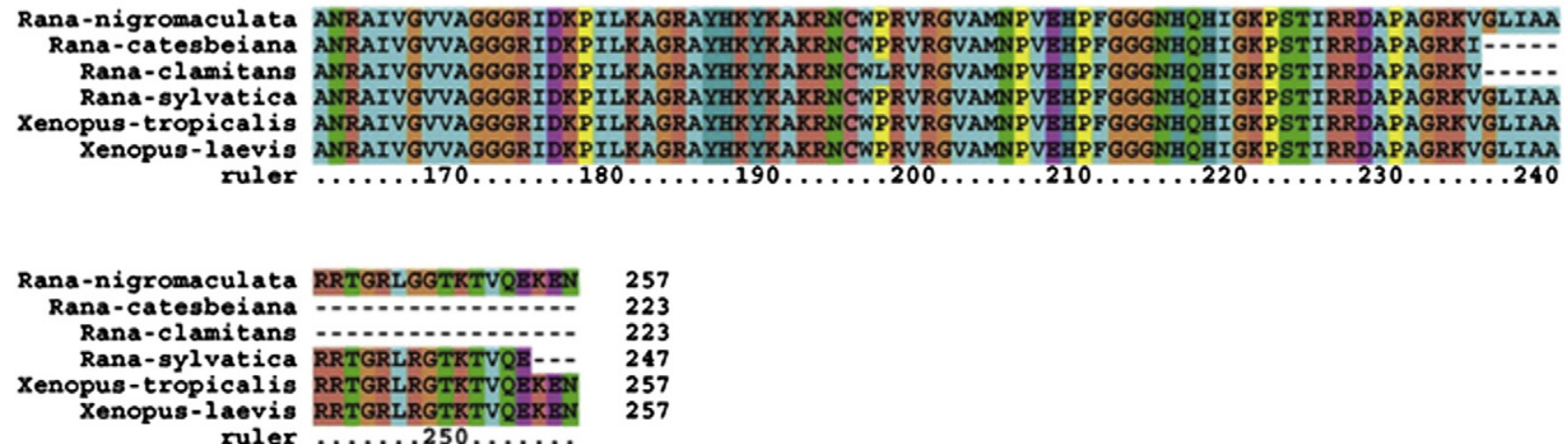

ruler ......250.......

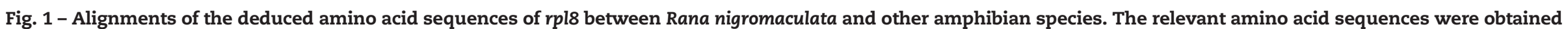

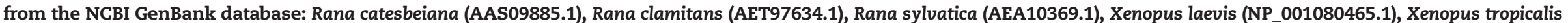
(NP_988925.1). Hyphens denote that the bases are gaps with those in the top line. The number on the right and bottom means the length of the amino acid sequences. 
Table 2 - Nucleotide and amino acid sequence identity of rpl8 between Rana nigromaculata and other amphibian

species.

Amphibian species

Rana nigromaculata

\begin{tabular}{lcc}
\cline { 2 - 3 } & Nucleotide & Amino acid \\
\hline Rana catesbeiana & $98 \%$ & $99 \%$ \\
Rana clamitans & $98 \%$ & $99 \%$ \\
Rana sylvatica & $97 \%$ & $99 \%$ \\
Xenopus laevis & $89 \%$ & $98 \%$ \\
Xenopus tropicalis & $88 \%$ & $98 \%$ \\
\hline
\end{tabular}

\section{Results}

2.1. Full length cDNA sequence of $r p l 8$ of $\mathbf{R}$. nigromaculata and homologic analysis

To obtain the full-length sequence of rpl8 cDNA of $R$. nigromaculata, we conducted RT-PCR and RACE. The sequence was submitted to the GenBank (GenBank accession number: KF585213). The rpl8 cDNA of R. nigromaculata was a transcript of $919 \mathrm{bp}$ that contained an open reading frame (ORF) of $774 \mathrm{bp}$ from 59 to $832 \mathrm{bp}$, which encoded a peptide of 257 amino acids (Fig. 1). R. nigromaculata had higher identity of nucleotide sequence with three Rana species (97\%-98\%) than with X. laevis (89\%) and X. tropicalis (88\%). Correspondingly, the identity of amino acid sequences between $R$. nigromaculata and three species of the Rana genus was $99 \%$. The identity of amino acid sequences between $R$. nigromaculata and $X$. laevis also reached $98 \%$ (Table 2).

\subsection{Expression of rpl8 and ef1a1 during R. nigromaculata development}

Using SYBR Green-based qRT-PCR, we investigated mRNA expression of rpl8 and ef $1 a 1$ in the brain, liver, intestine, tail, testis and ovary during $R$. nigromaculata development. No stage-specific difference in rpl8 mRNA expression was found among all tissues examined during $R$. nigromaculata development from Gosner stage 26 to stage 46 (Fig. 2). Also, there was no tissue-specific difference in rpl8 mRNA expression in these tissues at each developmental stage (Fig. 2). By contrast, ef1a1 expression was changeable in different tissues during development. Compared with ef1a1, rpl8 exhibited a more stable expression in different tissues during $R$. nigromaculata development.
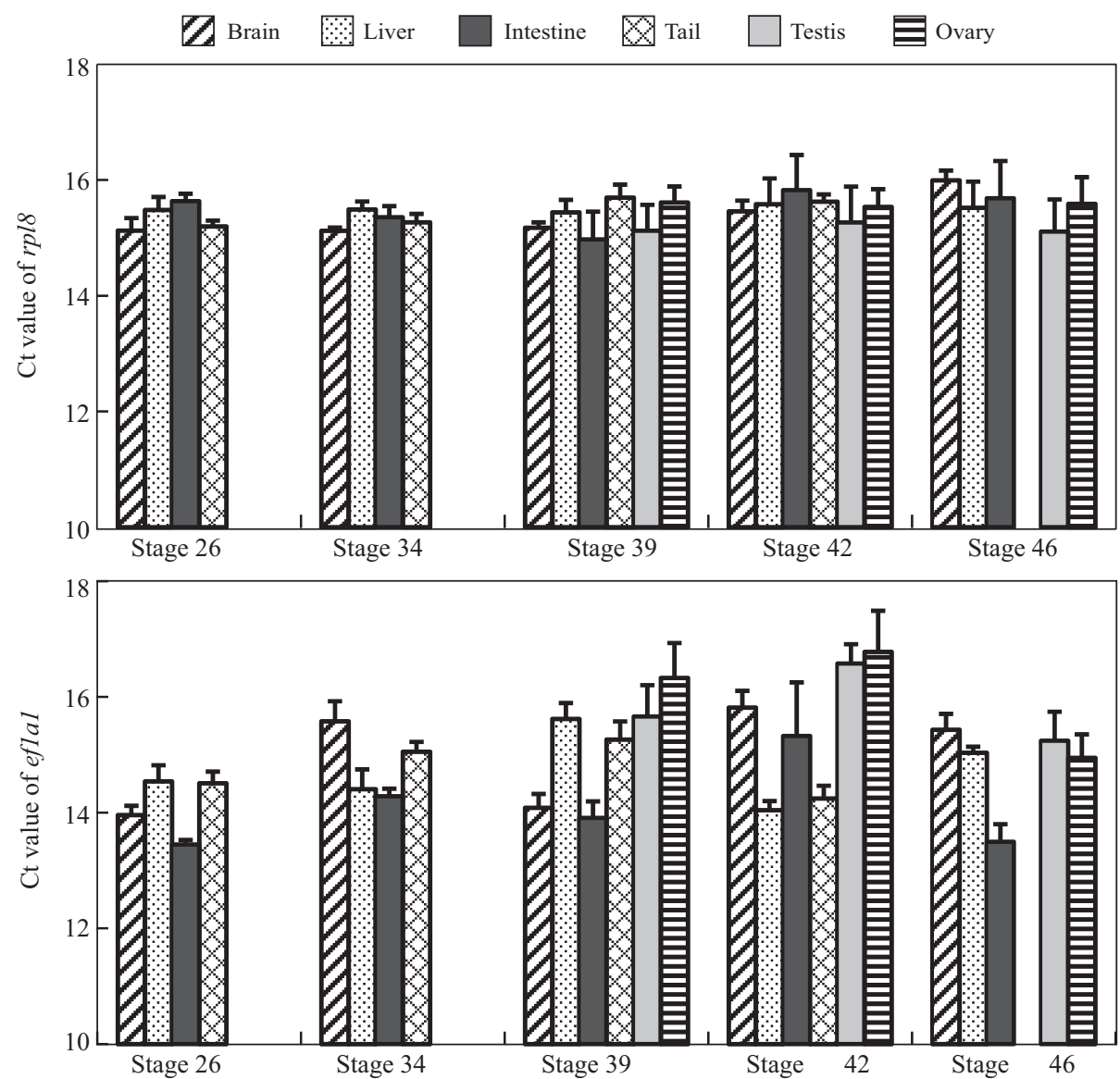

Fig. 2 - The mRNA expression of $r p l 8$ (a) and ef1a1 (b) in different tissues during Rana nigromaculata development. There was no data on the tails at stage 46 due to their loss at this stage. There was no data on the gonads before stage 39 due to the difficulty in distinguishing between the testis and the ovary. 


\subsection{Response of rpl8, ef1a1 and TRß expression to TH}

In the 2-day T4-exposure experiment of $R$. nigromaculata tadpoles at stage 27, we found that $\mathrm{T} 4$ had no effect on rpl8 mRNA expression (Fig. 3a), but raised slightly the ef1a1 mRNA expression at 0.01 and $10 \mathrm{nmol} / \mathrm{L}$ (Fig. 3b) and induced an increase in TR $\beta$ mRNA expression in the intestine in a concentration-dependent manner compared with the control (Fig. 3c).
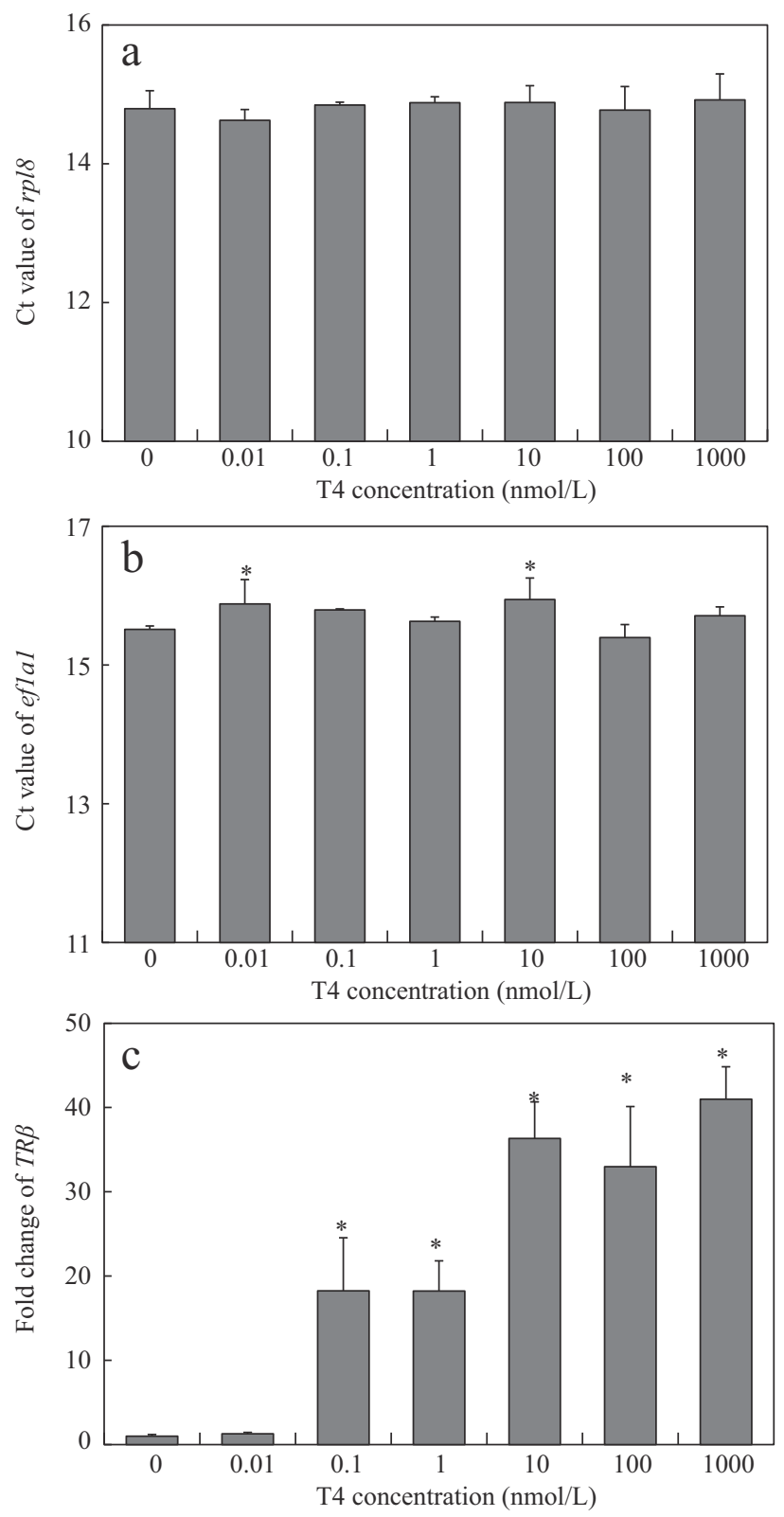

Fig. 3 - Effects of T4 on mRNA expression of rpl8 (a), ef1a1 (b) and $T R \beta$ (c) in intestine tissues of Rana nigromaculata tadpoles. Data were shown as means $\pm \operatorname{SD}(n=6)$. Significant differences between T4 treatment groups and the control were indicated by * (one-way analysis of variance, $p \leq 0.05$ ).

\subsection{Response of rpl8, ef1a1 and ERa expression to E2}

In the 4-day E2-exposure experiment of $R$. nigromaculata tadpoles at stage 42, we found that E2 had no effect on rpl8 expression, but up-regulated ef1a1 expression in $1 \mathrm{nmol} / \mathrm{L}$ and promoted ER $\alpha$ expression in liver tissues of the females in a
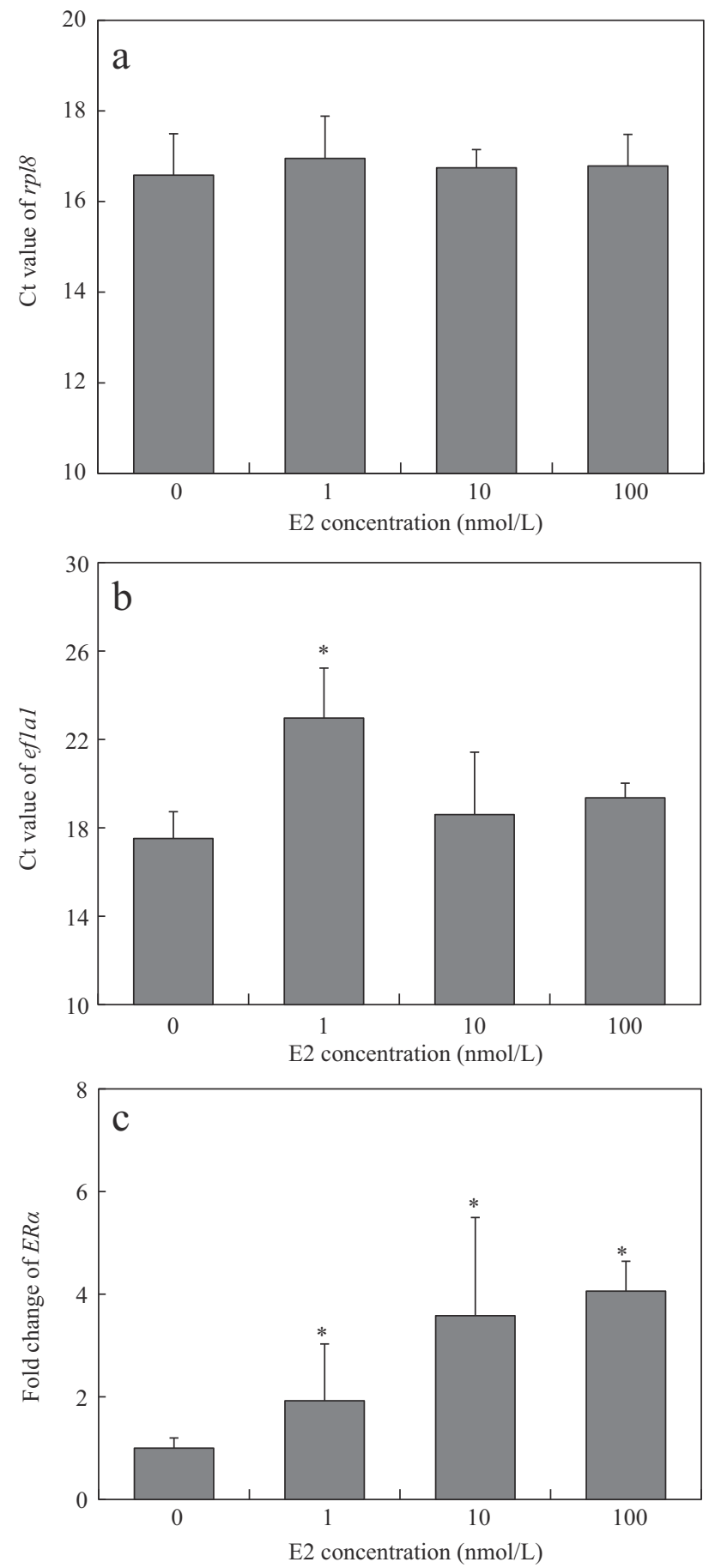

Fig. 4 - Effects of E2 on mRNA expression of rpl8 (a), ef1a1 (b) and $E R \alpha(c)$ in liver tissues of female Rana nigromaculata tadpoles. Data were shown as means \pm SD (n: $5-8)$. Significant differences between $\mathrm{E} 2$ treatment groups and the control were indicated by * (one-way analysis of variance, $p \leq 0.05$ ). 
concentration-dependent manner compared with the control (Fig. 4).

\section{Discussion}

Although rpl8 as the reference gene has been used to analyze gene expression in some frog species, the rpl8 nucleotide sequences of many species including $R$. nigromaculata have been unknown. In this study, we for the first time obtained the ORF of rpl8 in R. nigromaculata (774 bp, encoding a peptide of 257 amino acids). R. nigromaculata had high identities of nucleotide sequence and amino acid sequence with the known sequences of rpl8 from three frogs ( $R$. catesbeiana, R. clamitans, and R. sylvatica) of the Rana genus. Although the nucleotide sequence identity of rpl8 between $R$. nigromaculata and Xenopus species was only $88 \%-89 \%$, their identity of amino acid sequence reached $98 \%$ (Table 2). These results show that rpl8 has very high identity among amphibian species. Furthermore, the data demonstrate that $R$. nigromaculata has higher identity with the Rana genus than with $X$. laevis and X. tropicalis, which accords with the fact that $R$. nigromaculata has a closer evolutionary relationship with the Rana genus than with Xenopus species (Frost et al., 2006).

The stable expression in various tissues during development is a requirement for the reference gene in analyzing gene expression, which is especially important for amphibians because they undergo a metamorphic process. Shi and Liang (1994) demonstrated ubiquitous expression of rpl8 gene at fairly constant levels during tadpole development as well as postmetamorphic X. laevis. Thus, rpl8 is used as the reference gene for analyzing gene expression in $X$. laevis research. So far, however, the expression stability of rpl8 has not been validated in Rana, although rpl8 has been used as the reference gene for analyzing gene expression in some species of the Rana genus including R. nigromaculata (Gunderson et al., 2011; Hogan et al., 2007). For example, Zhang et al. (2013) used rpl8 to normalize mRNA expression of sex-related genes to investigate toxic effects of microcystin-LR on $R$. nigromaculata using qRT-PCR, without validation of the suitability of rpl8 as the reference gene. In the present study, we for the first time described rpl8 expression during tadpole development (from stage 26 to stage 46 ) and demonstrated that rpl8 had little tissuespecific difference among various tissues in $R$. nigromaculata. Compared with ef1a1, rpl8 was more stable and suitable as a reference gene in research on $R$. nigromaculata. It needs to be emphasized that we only demonstrated the expression stability of rpl8 during tadpole development, because tadpoles, but not embryos or frogs, are used to assay EDCs. It is unclear whether rpl8 expression is stable during embryonic development of R. nigromaculata. Recently, several studies reported that rpl8 expression was not stable in X. laevis and X. tropicalis during embryogenesis, suggesting that $r p l 8$ is unsuitable as a reference gene for analyzing gene expression in this developmental period of this amphibian species by qRT-PCR (Dhorne-Pollet et al., 2013; Sindelka et al., 2006). In the literature, in fact, many researchers used rpl8 as the reference gene for analyzing gene expression in $\mathrm{X}$. laevis and $\mathrm{X}$. tropicalis during embryonic development (Langlois et al., 2010; Morvan-Dubois et al., 2008). The cases of X. laevis and X. tropicalis highlight the fact that it is necessary to validate the suitability of a candidate gene as the reference gene prior to use. Thus, if the study involves the gene expression of $R$. nigromaculata during embryonic development, it is necessary to validate the expression suitability of rplo in this period.

Although housekeeping genes are expressed constitutively in every cell during development, it does not mean that their expression is not regulated in the cells of various tissues under certain experimental conditions (Bustin and Nolan, 2004; Huggett et al., 2005). In particular, the expression of housekeeping genes might be altered following exposure to some chemicals (Arukwe, 2006; Filby and Tyler, 2007). So, it is essential to validate the suitability of a housekeeping gene as the reference gene in a specific toxicological experiment (Arukwe, 2006). Our primary study has shown that $R$. nigromaculata is a promising native species for evaluating endocrine-disrupting effects of chemicals, especially on thyroid disruption and reproductive endocrine disruption (unpublished data). In the present study, we used T4 and E2 as positive reference chemicals to investigate whether thyroid disruptors and estrogenic chemicals had influences on rpl8 and ef1a1 expression in $R$. nigromaculata. Consequentially, we found that the expression of ef1a1 was not very steady in our experimental systems, however rpl8 mRNA expression was not altered by exposure to either T4 or E2, suggesting that rpl8 is suitable as the reference gene for analyzing gene expression in $R$. nigromaculata studies on EDC. Given the high conservation of rpl8 among the Rana genus, our results might provide support for using rpl8 as the reference gene for analyzing gene expression in other species of the Rana genus.

\section{Conclusions}

Our results show that rpl8 is an appropriate reference gene for analyzing gene expression by qRT-PCR for assaying EDCs using $R$. nigromaculata, and might also provide support for using rpl8 as a reference gene in other Rana species due to the high conservation of rpl8 among the Rana genus.

\section{Acknowledgments}

This work was supported by the National High Technology Research and Development Program (863) of China (No. 2012AA06A302), the Public Welfare Research Project for Environmental Protection (No. 201109048), and the National Natural Science Foundation of China (No. 21077125).

\section{R E F E R E N C E S}

Arukwe, A., 2006. Toxicological housekeeping genes: do they really keep the house? Environ. Sci. Technol. 40 (24), 7944-7949.

Berg, C., Gyllenhammar, I., Kvarnryd, M., 2009. Xenopus tropicalis as a test system for developmental and reproductive toxicity. J. Toxicol. Environ. Health A 72 (3-4), 219-225.

Burggren, W.W., Warburton, S., 2007. Amphibians as animal models for laboratory research in physiology. ILAR J. 48 (3), 260-269. 
Bustin, S.A., Nolan, T., 2004. Pitfalls of quantitative real-time reverse-transcription polymerase chain reaction. J. Biomol. Tech. 15 (3), 155-166.

Croteau, M.C., Davidson, M., Duarte-Guterman, P., Wade, M., Popesku, J.T., Wiens, S., et al., 2009. Assessment of thyroid system disruption in Rana pipiens tadpoles chronically exposed to UVB radiation and 4-tert-octylphenol. Aquat. Toxicol. 95 (2), 81-92.

Degitz, S.J., Holcombe, G.W., Flynn, K.M., Kosian, P.A., Korte, J.J., Tietge, J.E., 2005. Progress towards development of an amphibian-based thyroid screening assay using Xenopus laevis. Organismal and thyroidal responses to the model compounds 6-propylthiouracil, methimazole, and thyroxine. Toxicol. Sci. 87 (2), 353-364.

Dhorne-Pollet, S., Thelie, A., Pollet, N., 2013. Validation of novel reference genes for RT-qPCR studies of gene expression in Xenopus tropicalis during embryonic and post-embryonic development. Dev. Dyn. 242 (6), 709-717.

Filby, A.L., Tyler, C.R., 2007. Appropriate 'housekeeping' genes for use in expression profiling the effects of environmental estrogens in fish. BMC Mol. Biol. 8, 10.

Fini, J.B., Le Mevel, S., Palmier, K., Darras, V.M., Punzon, I., Richardson, S.J., et al., 2012. Thyroid hormone signaling in the Xenopus laevis embryo is functional and susceptible to endocrine disruption. Endocrinology 153 (10), 5068-5081.

Frost, D.R., Grant, T., Faivovich, J., Bain, R.H., Haas, A., Haddad, C.F.B., et al., 2006. The amphibian tree of life. Bull. Am. Mus. Nat. Hist. 297, 8-370.

Gosner, K.L., 1960. A simplified table for staging anuran embryos and larvae with notes on identification. Herpetologica 16 (3), 183-190.

Gunderson, M.P., Veldhoen, N., Skirrow, R.C., Macnab, M.K., Ding, W., Van Aggelen, G., et al., 2011. Effect of low dose exposure to the herbicide atrazine and its metabolite on cytochrome P450 aromatase and steroidogenic factor-1 mRNA levels in the brain of premetamorphic bullfrog tadpoles (Rana catesbeiana). Aquat. Toxicol. 102 (1-2), 31-38.

Hayes, T.B., Stuart, A.A., Mendoza, M., Collins, A., Noriega, N., Vonk, A., et al., 2006. Characterization of atrazine-induced gonadal malformations in African clawed frogs (Xenopus laevis) and comparisons with effects of an androgen antagonist (cyproterone acetate) and exogenous estrogen (17 betaestradiol): support for the demasculinization/feminization hypothesis. Environ. Health Perspect. 114 (S1), 134-141.

Heimeier, R.A., Shi, Y.B., 2010. Amphibian metamorphosis as a model for studying endocrine disruption on vertebrate development: effect of bisphenol A on thyroid hormone action. Gen. Comp. Endocrinol. 168 (2), 181-189.

Hinther, A., Bromba, C.M., Wulff, J.E., Helbing, C.C., 2011. Effects of triclocarban, triclosan, and methyl triclosan on thyroid hormone action and stress in frog and mammalian culture systems. Environ. Sci. Technol. 45 (12), 5395-5402.

Hogan, N.S., Crump, K.L., Duarte, P., Lean, D.R.S., Trudeau, V.L., 2007. Hormone cross-regulation in the tadpole brain: developmental expression profiles and effect of $\mathrm{T} 3$ exposure on thyroid hormone-and estrogen-responsive genes in Rana pipiens. Gen. Comp. Endocrinol. 154 (1-3), 5-15.

Hogan, N.S., Duarte, P., Wade, M.G., Lean, D.R.S., Trudeau, V.L., 2008. Estrogenic exposure affects metamorphosis and alters sex ratios in the northern leopard frog (Rana pipiens): identifying critically vulnerable periods of development. Gen. Comp. Endocrinol. 156 (3), 515-523.

Huggett, J., Dheda, K., Bustin, S., Zumla, A., 2005. Real-time RT-PCR normalisation; strategies and considerations. Genes Immun. 6 (4), 279-284.

Kloas, W., Lutz, I., 2006. Amphibians as model to study endocrine disrupters. J. Chromatogr. A 1130 (1), 16-27.

Kloas, W., Lutz, I., Springer, T., Krueger, H., Wolf, J., Holden, L., et al., 2009. Does atrazine influence larval development and sexual differentiation in Xenopus laevis? Toxicol. Sci. 107 (2), 376-384.

Langlois, V.S., Duarte-Guterman, P., Ing, S., Pauli, B.D., Cooke, G.M., Trudeau, V.L., 2010. Fadrozole and finasteride exposures modulate sex steroid- and thyroid hormone-related gene expression in Silurana (Xenopus) tropicalis early larval development. Gen. Comp. Endocrinol. 166 (2), 417-427.

Lehigh Shirey, E.A., Jelaso Langerveld, A., Mihalko, D., Ide, C.F., 2006. Polychlorinated biphenyl exposure delays metamorphosis and alters thyroid hormone system gene expression in developing Xenopus laevis. Environ. Res. 102 (2), 205-214.

Li, X.Y., Zhou, J., Yu, M., Wang, J.J., Pei, Y.C., 2009. Toxic effects of 1-methyl-3-octylimidazolium bromide on the early embryonic development of the frog Rana nigromaculata. Ecotoxicol. Environ. Saf. 72 (2), 552-556.

Lutz, I., Blodt, S., Kloas, W., 2005. Regulation of estrogen receptors in primary cultured hepatocytes of the amphibian Xenopus laevis as estrogenic biomarker and its application in environmental monitoring. Comp. Biochem. Physiol. C Pharmacol. Toxicol. Endocrinol. 141 (4), 384-392.

Morse, D.L., Carroll, D., Weberg, L., Borgstrom, M.C., Ranger-Moore, J., Gillies, R.J., 2005. Determining suitable internal standards for mRNA quantification of increasing cancer progression in human breast cells by real-time reverse transcriptase polymerase chain reaction. Anal. Biochem. 342 (1), 69-77.

Mortensen, A.S., Kortner, T.M., Arukwe, A., 2006. Thyroid hormone-dependent gene expression as a biomarker of short-term 1,1-dichloro-2,2-bis (p-chlorophenyl) ethylene (DDE) exposure in European common frog (Rana temporaria) tadpoles. Biomarkers 11 (6), 524-537.

Morvan-Dubois, G., Demeneix, B.A., Sachs, L.M., 2008. Xenopus laevis as a model for studying thyroid hormone signalling: from development to metamorphosis. Mol. Cell. Endocrinol. 293 (1-2), 71-79.

Oka, T., Miyahara, M., Yamamoto, J., Mitsui, N., Fujii, T., Tooi, O., et al., 2009. Application of metamorphosis assay to a native Japanese amphibian species, Rana rugosa, for assessing effects of thyroid system affecting chemicals. Ecotoxicol. Environ. Saf. 72 (5), 1400-1405.

Park, S., Park, S.H., Ahn, H.C., Kim, S., Kim, S.S., Lee, B.J., 2001. Structural study of novel antimicrobial peptides, nigrocins, isolated from Rana nigromaculata. FEBS Lett. 507 (1), 95-100.

Qin, Z.F., Qin, X.F., Yang, L., Han-Ting, L., Zhao, X.R., Xu, X.B., 2007. Feminizing/demasculinizing effects of polychlorinated biphenyls on the secondary sexual development of Xenopus laevis. Aquat. Toxicol. 84 (3), 321-327.

Shi, Y.B., Liang, V.C.T., 1994. Cloning and characterization of the ribosomal-protein L8 gene from Xenopus laevis. Biochim. Biophys. Acta 1217 (2), 227-228.

Sindelka, R., Ferjentsik, Z., Jonak, J., 2006. Developmental expression profiles of Xenopus laevis reference genes. Dev. Dyn. 235 (3), 754-758.

Song, F.Y., Li, B.B., Stocum, D.L., 2010. Amphibians as research models for regenerative medicine. Organogenesis 6 (3), 141-150.

State Science and Technology Commission in China, 1988. Regulation for the Administration of Affairs Concerning Experimental Animals. The Ministry of Science and Technology of the People's Republic of China, Beijing.

Takase, M., Mitsui, N., Oka, T., Tooi, O., Santo, N., Pickford, D.B., et al., 2007. Development of biomarkers of endocrine disrupting activity in emerging amphibian model, Silurana (Xenopus) tropicalis. Environ. Sci. 14 (6), 285-296.

Tan, S.W., Zoeller, R.T., 2007. Integrating basic research on thyroid hormone action into screening and testing programs for thyroid disruptors. CRC Crit. Rev. Toxicol. 37 (1-2), 5-10.

Tata, J.R., Baker, B.S., Machuca, I., Rabelo, E.M.L., Yamauchi, K., 1993. Autoinduction of nuclear receptor genes and its significance. J. Steroid Biochem. Mol. Biol. 46 (2), 105-119. 
Veldhoen, N., Skirrow, R.C., Osachoff, H., Wigmore, H., Clapson, D.J., Gunderson, M.P., et al., 2006. The bactericidal agent triclosan modulates thyroid hormone-associated gene expression and disrupts postembryonic anuran development. Aquat. Toxicol. 80 (3), 217-227.

Yang, F.X., Xu, Y., Wen, S., 2005. Endocrine-disrupting effects of nonylphenol, bisphenol A, and p, p'-DDE on Rana nigromaculata tadpoles. Bull. Environ. Contam. Toxicol. 75 (6), 1168-1175.
Zhang, H.J., Cai, C.C., Wu, Y.Z., Ye, B.H., Han, L., Shou, X.L., et al., 2013. Toxic effects of microcystin-LR on the reproductive system of male Rana nigromaculata in vitro. Aquat. Toxicol. 126, 283-290. 